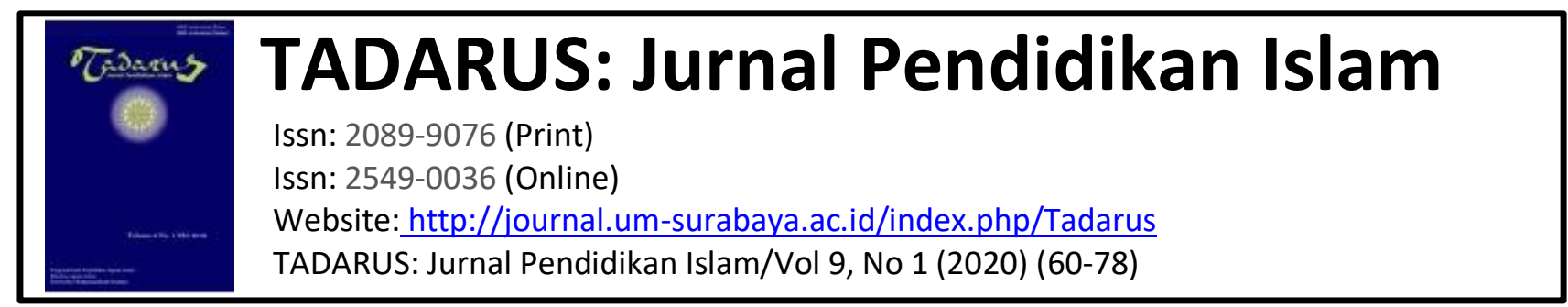

\title{
PENINGKATAN KEMAMPUAN SISWA PADA PEMAHAMAN \\ BIDANG STUDI AL ISLAM DENGAN PEMBELAJARAN BERBASIS KONSTRUKTIVISTIK KONTEKSTUAL DI SMPMUHAMMADIYAH 10 SURABAYA
}

\author{
${ }^{1}$ Amrozi, ${ }^{2}$ Asrori \\ 1elbadriyah lila@yahoo.com, ${ }^{2}$ asrori@ fai.um-surabaya.ac.id \\ Program Studi Pendidikan Agama Islam, UniversitasMuhammadiyah Surabaya
}

\begin{abstract}
Abstrak
Masih banyak guru yang menggunakan pembelajaran konvensional untuk bidang studi al-Islam, tentu saja tidak relevan. Mereka beralasan metode ini lebih mudah dilaksanakan. Pemecahan masalah pendidikan dengan kondisi di lapangan saat ini seperti tersebut di atas, sebenarnya telah dilakukan oleh pemerintah dengan berbagai pembaharuan, antara lain dengan pelatihan dan peningkatan kompetensi guru.

Metode yang di gunakan dalam penelitian adalah penelitian tindakan kelas. Penelitian yang dilakukan dengan menekankan adanya niat yang tinggi untuk bertindak memecahkan masalah dan menyempurnakan situasi. Ini merupakan pencermatan terhadap kegiatan yang sengaja dimunculkan, dan terjadi dalam sebuah kelas.

Berdasarkan penelitian pada siklus 1, 2 dan 3 diperoleh simpulan sebagai berikut: Kemampuan guru dalam mengelola pembelajaran kontruktivistik yang kontekstual selama tiga siklus mengalami peningkatan. Padasiklus I yaitu dengan nilai rata-rata sebesar 2,41 dengan kategori baik, siklus II : 2,93 dengan kategori baik, dan siklus III sebesar 3,00 dengan kategori baik; 2. Aktivitas guru selama pembelajaran selama tiga siklus, 2. Ketuntasan belajar siswa secara klasikal pada siklus I yaitu 60\%, kemudian pada siklus II meningkat menjadi $88,89 \%$ danpadasiklus III menurun menjadi $86,67 \%$, 3. Respon siswa pada penerapan model pembelajaran kontruktivistik yang kontekstual dengan media patung manusia, air dan debu padamateri wudhu, tayamum dan mandi wajib yaitu dengan banyaknya siswa yang menjawab setuju sebesar $82,86 \%$.
\end{abstract}

Kata kunci: Konstruktivistik Kontekstual, Pemahaman Bidang Studi Al-Islam 


\section{Pendahuluan}

Pembelajaran Construvtivist Theories of Learning adalah model pembelajaran yang mengutamakan siswa secara aktif membangun pembelajaran mereka sendiri secara mandiri dan memindahkan informasi yang kompleks. Mengacu pada pemikiran Aronson yang mengatakan bahwa pada proses pembelajaran, guru memberikan kesempatan siswa dalam proses belajar dan sosialisasi yang berkesinambungan. ${ }^{1}$

Pendekatan kontekstual merupakan konsep belajar yang membantu guru mengaitkan antara materi yang diajarkannya denga situasi dunia nyata siswa dan mendorong siswa membuat hubungan antara pengetahuan yang dimilikinya dengan penerapannya dalam kehidupan mereka sebagai anggota keluarga dan masyarakat. Kontekstual merupakan suatu pendekatan pembelajaran yang menekankan pada proses keterlibatan siswa secara penuh untuk menemukan materi yang dipelajari dan menghubungkannya dengan situasi kehidupan nyata sehingga mendorong siswa untuk dapat menerapkannya pada kehidupan mereka ${ }^{2}$

Pembelajaran kontruktivistik kontekstual dapat dijalankan tanpa harus mengubah kurikulum dan tatanan yang ada, dengan pendekatan konstektual anak belajar dari pengalaman sendiri, mengkonstruksi pengetahuan, kemudian memberi makna pada pengetahuan itu. Anak mencatat sendiri pola-pola bermakna dari pengetahuan baru, dan bukan diberi begitu saja oleh guru. Pembelajaran konstruktivistik atau Construvtivist Theories of Learning adalah model pembelajaran yang mengutamakan siswa secara aktif membangun pembelajaran mereka sendiri secara mandiri dan memindahkan informasi yang kompleks. Mengacu pada pemikiran Aronson yang mengatakan bahwa pada proses pembelajaran, guru memberikan kesempatan siswa dalam proses belajar dan sosialisasi yang berkesinambungan. ${ }^{3}$ Pendekatan ini mengasumsikan bahwa siswa datang ke ruang kelas dengan membawa ide - ide, keyakinan, dan pandangan yang perlu diubah atau dimodifikasi oleh seorang guru yang memfasilitasi perubahan ini, dengan merancang tugas dan pertanyaan yang menantang seperti membuat dilema untuk diselesaikan oleh peserta didik. ${ }^{4}$

\footnotetext{
1, John A Zahorik, Construvtivist Teaching, (Bloomington, Indiana: Phi-Delta Kappa Educational Foundation, 1995), 72

2 Wina Sanjaya, Pembelajaran Dalam Implementasi Kurikulum Berbasis Kompetensi, (Jakarta: Kencana, 2005), 109

${ }^{3}$ DaveMaier, The Accelerated Learning, (New York: Mc.Graw-Hill, 2000), 75

${ }^{4}$ Muhammad, Yaumi, Prinsip-Prinsip Desain Pembelajaran, (Jakarta: Fajar Interpratama Mandiri, 2013), 42
} 
Menurut Zahorik ada lima elemen yang harus diperhatikan dalam praktek pembelajaran berbasis kontruktivistik yang kontekstual: ${ }^{5}$

1. Pengaktifan pengetahuan yang sudah ada

2. Pemerolehan pengetahuan baru dengan cara mempelajari secara keselurahan dulu, kemudian memperhatikan detailnya.

3. Pemahaman pengetahuan, yaitu dengan cara menyusun (1) konsep sementara (hipotesis), (2) melakukan diskusi kepada orang lain agara mendapat tanggapan (validasi) dan atas dasar tanggapan itu, dan (3) konsep tersebut direvisi lalu dikembangkan.

4. Mempraktekkan pengetahuan, pengalaman.

5. Melakukan refleksi terhadap strategi pengembangan pengetahuan tersebut.

Model pembelajaran kontruktivistik kontekstual dimaksudkan menjadikan kebiasaan guru yang bersifat otoriter menjadi fasilitator, mengubah kegiatan pembelajaran ego-involvement, menjadi task-involvement, sehingga proses pembelajaran menjadi lebih efektif serta dapat; membangkitkan minat siswa untuk belajar menemukan sendiri, bekerja sama dan mengomunikasikan hasil belajarnya, dan siswa semakin aktif serta kooperatif. Dengan pembelajaran berbasis kontruktivistik yang kontektual diharapkan siswa dapat memahmi materi pelajaran dan lebih bermakna bagi siswa, karena proses pembelajaran berlangsung alamiah dalam bentuk kegiatan siswa bekerja dan mengalami. ${ }^{6}$

Dengan latar belakang masalah di atas penulis ingin meneliti tentang: Peningkatan Kemampuan Siswa Pada Pemahaman Bidang Studi Al-Islam Dengan Pembelajaran Berbasis Konstruktivistik Kontekstual di SMP Muhammadiyah 10 Surabaya

\section{Metodologi Penelitian}

Jenis penelitian ini adalah penelitian tindakan kelas, Menurut Asrori, penelitian tindakan kelas adalah sebuah kegiatan yang dilaksanakan untuk mengamati kejadiankejadian dalam kelas terbingkai dalam beberapa waktu atau siklus dengan metode kontekstual artinya variable-variable yang akan dipahami selalu berkaitan dengan kondisi kelas itu sendiri. Penelitian tindakan kelas bukan hanya bertujuan

\footnotetext{
${ }^{5}$ Asrori, Inovasi Belajar \& Pembelajaran PAI: Teori Aplikaif, (Surabaya: UM Surabaya Press, 2019), 254

${ }^{6}$ Jamaluddin, Pembelajaran Yang Efektif, (Jakarta: BagianProyrkEMISPerguruan Agama Islam TingkatDasar, 2001), 36
} 
mengungkap penyebab berbagai permasalahan pembelajaran yang dihadapi seperti kesulitan siswa mempelajari pokok pembahasan tertentu, tetapi lebih penting lagi adalah memberikan pemecahan masalah berupa tindakan tertentu untuk meningkatkan kualitas proses dan hasil belajar. ${ }^{7}$ Penelitian tindakan kelas (Classroom Action Research) dilakukan dengan menekankan adanya niat yang tinggi untuk bertindak memecahkan masalah dan menyempurnakan situasi. ${ }^{8}$ Dan ini merupakan pencermatan terhadap kegiatan yang sengaja dimunculkan, dan terjadi dalam sebuah kelas.

Sehubungan dengan penelitian ini populasi yang diambil adalah semua siswa kelas VII SMP Muhammadiyah 10 Surabaya. Populasi ini memiliki ciri-ciri yang homogen. Kehomogenan populasi ini didasarkan pada kesamaan sistem pengajaran yang dipakai, bahan pengajaran yang ditempuh dan waktu yang disediakan untuk pengajaran al-Islam. Hal ini disebabkan oleh penggunaan kurikulum Sekolah Menengah Pertama yang menyajikan materi pemahaman wudhu, tayamum dan mandi wajib. Kehomogenitasan populasi dalam penelitian ini juga dikarenakan usia siswa kelas VII SMP Muhammadiyah 10 Surabaya yang relatif sama. Dengan demikian, siswa yang ditetapkan sebagai populasi adalah yang memenuhi persyaratan yaitu telah memiliki pengalaman belajar dengan kemampuan siswa dalam pemahaman materi dalam mata pelajaran al-Islam pokok bahasan wudhu, tayamum dan mandi wajib.

Berdasarkan asumsi bahwa populasi penelitian ini homogen, maka penguraian sampel dalam penelitian ini dilaksanakan dengan teknik cluster sampling (pengelompokkan). Dalam penelitian ini ditentukan jumlah sampel sebesar satu kelas yaitu terdiri dari 45 anak. Penentuan sampel ini didasarkan pendapat Sutrisno Hadi bahwa cluster sampling satu-satunya sampel tidak terdiri dari individu-individu melainkan kelompok-kelompok individu atau cluster-cluster. ${ }^{9}$

Teknik pengambilan data dalam penelitian ini dilakukan dengan penyebaran instrumen yaitu mengadakan tes kemampuan pemahaman pokok bahasan wudhu, tayamum dan mandi wajib dengan indicator (1) Siswa dapat menjelaskan pengertian taharah dan macam-macam taharah (2) siswa dapat menyebutkan macam-macam hadats serta najis dan cara menyucikannya. Prosedur dan alokasi waktu yang disediakan dilaksanakan berdasarkan pelaksanaan penelitian yang dilaksanakan.

\footnotetext{
${ }^{7}$ Asrori \& Rusman, Classroom Action Research Pengembangan Kompetensi Guru, (Purwokerto: Pena Persada, 2020), 5

${ }^{8}$ Sikidin, dkk, MetodologiPenelitrian, (Surabaya: InsanCendikia, 2005), hal 23

${ }^{9}$ SutrisnoHadi, MetodologiResearchII, (Yogyakarta: UGM, 1994), hal 85
} 


\section{Hasil dan Analisis Penelitian}

1. Hasil Penelitian

a. Siklus I

Pada siklus I pembelajaran dilakukan selama 2 X 40 menit, dimana 70 menit untuk kegiatan belajar mengajar dengan model pembelajaran deduktif dan 10 menit untuk melaksanakan tes akhir (postest). Adapun hasil pengamatan kegiatan pembelajaran pada siklus I disajikan pada tabel 1-4. Data hasil penilaian kemampuan guru dalam mengelola pembelajaran deduktif pada siklus I yang dinyatakan dengan rata-rata skor penilaian yang hasilnya disajikan pada tabel 1 .

Tabel 1: Pengelolaan Pembelajaran Deduktif

\begin{tabular}{|c|c|c|c|c|}
\hline \multirow{2}{*}{ No } & \multirow{2}{*}{ Aspek Yang Diamati } & \multicolumn{2}{|c|}{ Skor Pengamatan } & \multirow{2}{*}{ Kriteria } \\
\hline & & $X$ & $\mathrm{Y}$ & \\
\hline I & $\begin{array}{l}\text { A. Pendahuluan } \\
\text { 1. Mempersiapkan sarana pembelajaran } \\
\text { 2. Memotivasi siswa } \\
\text { 3. Menyampaikan indikator hasil pembelajaran } \\
\text { 4. Menghubungkan materi baru dengan pengetahuluan awal siswa }\end{array}$ & $\begin{array}{l}3 \\
3 \\
3 \\
2\end{array}$ & 2,75 & Baik \\
\hline II & $\begin{array}{l}\text { B. Kegiatan Inti Pembelajaran berbasis konruktivistik yang } \\
\text { kontekstual. } \\
\text { 1. Abstraksi } \\
\text { a. Penguasaan kelas } \\
\text { b. Penguasaan kemampuan menjelaskan } \\
\text { c. Penguasaan teknik bertanya } \\
\text { 2. Penyajian Ilustrasi } \\
\text { a. Penguasaan materi } \\
\text { b. Kemampuan mengkomunikasikan konsep dengan cara mengkaitkan } \\
\text { pengetahuan awal siswa } \\
\text { c. Kemampuan menyatakan contoh soal dengan penyelesaianya } \\
\text { 3. Contoh yang dibuat siswa } \\
\text { a. Kemampuan mengaktifkan siswa } \\
\text { b. Kemampuan membimbing siswa } \\
\text { c. Kemampuan memantau kesulitan siswa } \\
\text { d. Kemampuan memberikan umpan balik kepada siswa } \\
\text { 4. Penutup } \\
\text { a. Kemampuan membimbing siswa untuk mengikhtisarkan } \\
\text { b. Kemampuan menuliskan hasil diskusi pelajaran }\end{array}$ & $\begin{array}{l}2 \\
2 \\
2 \\
2\end{array}$ & 2,5 & Sedang \\
\hline III & $\begin{array}{l}\text { C. Penutup } \\
\text { Mennginformasikan kepada siswa untuk mempelajari materi } \\
\text { berikutnya dan mempersiapkan post test }\end{array}$ & 3 & 3 & Baik \\
\hline IV & Pengelolaan waktu & 2 & 2 & Sedang \\
\hline V & $\begin{array}{l}\text { Pengamatan Suasana Kelas } \\
\text { A. antusiasme } \\
\text { 1. Guru antusias } \\
\text { 2. Siswa antusias }\end{array}$ & $\begin{array}{l}3 \\
3 \\
\end{array}$ & 3 & Baik \\
\hline
\end{tabular}

Dari table I dapat diperoleh nilai rata-rata kemampuan guru dalam mengelola pembelajaran pada siklus I sebesar 2,41. Ini menunjukkan bahwa pembelajaran 
yang dilaksanakan pada sklus I dengan kategori baik. Namun dalam aspek tertentu masih terdapat kekurangan yaitu pada aspek pengelolaan waktu (2) dan pada kegiatan inti (2). Hal ini disebabkan siswa belum memahami prinsip dari belajar dengan model pembelajaran, sehingga guru dalam mengelola kelas belum maksimal. Data hasil pengamatan aktivitas guru dalam kegiatan model pembelajaran berbasis kontruktivistik yng kontekstual pada siklus I disajikan pada tabel 2.

Tabel 2: Persentase Aktivitas Guru Pada Siklus I

\begin{tabular}{|l|l|r|}
\hline No & Aktivitas guru & \% Aktivitas \\
\hline 1 & Menyampaikan materi & $33,33 \%$ \\
\hline 2 & Mengamati kegiatan siswa & $16,67 \%$ \\
\hline 3 & Memberikan latihan terbimbing & $13,33 \%$ \\
\hline 4 & Memberikan umpan balik & $10 \%$ \\
\hline 5 & Memotivasi siswa & $6,67 \%$ \\
\hline 6 & Berdiskusi/bertanya dengan siswa & $10 \%$ \\
\hline 7 & Perilaku yang tidak relevan & $10 \%$ \\
\hline
\end{tabular}

Dari tabel 2 aktivitas guru yang dominan adalah menyampaikan materi sebesar $33,33 \%$, dibandingkan dengan aktivitas guru yang lainnya yaitu mengamati kegiatan siswa 16,67 \%, Memberikan latihan terbimbing 13,33\%, Memberikan umpan balik $10 \%$, Memotivasi siswa $10 \%$, Berdiskusi/bertanya dengan siswa 6,67 \%, Perilaku yang tidak relevan $10 \%$. Sehingga pembelajaran masih berpusat pada guru dan menyebabkan siswa kurang diberi kesempatan untuk terlibat secara aktif dalam kegiatan belajar mengajar. Data hasil pengamatan aktivitas siswa dalam kegiatan model pembelajaran pada siklus I disajikan pada tabel 3.

Tabel 3: Persentase Aktivitas Siswa Pada Siklus I

\begin{tabular}{|l|l|r|}
\hline No & Aktivitas siswa & \% Aktivitas \\
\hline 1 & Mendengarkan penjelasan guru & $36,67 \%$ \\
\hline 2 & Menyelesaikan tugas dari guru & $13,33 \%$ \\
\hline 3 & $\begin{array}{l}\text { Membaca buku, LKS } \\
\text { (termasuk melihat penampilan media) }\end{array}$ \\
\hline 4 & Berdiskusi/ bertanya dengan guru & $10 \%$ \\
\hline 5 & Berdiskusi/ bertanya antar siswa & $10 \%$ \\
\hline 6 & Perilaku yang tidak relevan & $10 \%$ \\
\hline
\end{tabular}


Dari tabel 3 dapat dilihat bahwa siswa kurang berperan aktif dalam proses belajar mengajar. Hal ini dikarenakan tingginya aktivitas siswa sebesar 36,67\% dibandingkan dengan aktivitas siswa yang lainnya, yaitu menyelesaikan tugas dari guru yaitu sebesar 13,33\%, berdiskusi/bertanya dengan guru sebesar 10\%, berdisusi/bertanya antar siswa $10 \%$ dan perilaku yang tidak relevan 10\%. Pada akhir pembelajaran deduktifsiklus I dilakukan postest I. data ketuntasan klasikal hasil postest I siswa kelas X disajikan pada tabel 4.

Tabel 4: Ringkasan Hasil Postest pada siklus I

\begin{tabular}{|c|l|r|}
\hline No & Karakteristik & \multicolumn{1}{|c|}{ Nilai } \\
\hline 1 & Jumlah Siswa & 45 \\
\hline 2 & Jumlah siswa yang tuntas $(\geq 66)$ & 18 \\
\hline 3 & Jumlah siswa yang tidak tuntas $(<66)$ & $60 \%$ \\
\hline 4 & $\%$ ketuntasan klasikal & 27 \\
\hline
\end{tabular}

Berdasarkan hasil yang diperoleh dari postest I, dapat ditunjukkan ahwa pada siklus I ini diperoleh ketuntasan klasikal sebesar 60\% Hal ini berarti ketuntasan klasikal belum tercapai. (dibawah Standar Ketuntasan Belajar Minimal) sebesar 85\%. Hasil analisis secara lengkap, postest I siklus I dapat dilihat pada lampiran.

b. Siklus II

Pada siklus II pembelajaran dilakukan selama 2X40 menit, dimana 70 menit untuk kegiatan belajar mengajar dengan model pembelajaran dan 10 menit untuk melaksanakan tes akhir (postest). Adapun hasil pengamatan kegiatan pembelajaran deduktif pada siklus II disajikan pada tabel 5-8. Data hasil penilaian kemampuan guru dalam mengelola pembelajaran deduktif pada siklus II yang dinyatakan dengan ratarata skor penilaian yang hasilnya disajikan pada tabel 5 .

Tabel 5: Pengelolaan Pembelajaran

\begin{tabular}{|l|l|c|c|c|}
\hline No & \multicolumn{1}{|c|}{ Aspek Yang Diamati } & \multicolumn{2}{c|}{ Skor Pengamatan } & \multirow{2}{*}{ Kriteria } \\
\cline { 3 - 4 } & & X & \\
\hline I & A. Pendahuluan & 3 & & \\
& 1. Mempersiapkan sarana pembelajaran & 3 & 3 & \multirow{2}{*}{ Baik } \\
& 2. Memotivasi siswa & 3 & & \\
& 3. Menyampaikan indikator hasil pembelajaran & 3 & & \\
\cline { 2 - 4 } & 4. Menghubungkan materi baru dengan pengetahuluan awal siswa & 3 & \\
\hline
\end{tabular}




\begin{tabular}{|c|c|c|c|c|}
\hline II & $\begin{array}{l}\text { B.Kegiatan Inti Pembelajaran berbsis kontruktivistik dengan } \\
\text { endekatan kontekstual } \\
\text { 1. Abstraksi } \\
\text { a. Penguasaan kelas } \\
\text { b. Penguasaan kemampuan menjelaskan } \\
\text { c. Penguasaan teknik bertanya } \\
\text { 2. Penyajian Ilustrasi } \\
\text { a. Penguasaan materi } \\
\text { b. Kemampuan mengkomunikasikan konsep dengan cara } \\
\text { mengkaitkan pengetyahuan awal siswa } \\
\text { c. Kemampuan menyatakan contoh soal dengan } \\
\text { 3. Contohyelesaianya yang dibuat siswa } \\
\text { a. Kemampuan mengaktifkan siswa } \\
\text { b. Kemampuan membimbing siswa } \\
\text { c. Kemampuan memantau kesulitan siswa } \\
\text { d. Kemampuan memberikan umpan balik kepada siswa } \\
\text { 4. Penutup } \\
\text { a. Kemampuan membimbing siswa untuk mengikhtisarkan } \\
\text { b. Kemampuan menuliskan hasil diskusi ikhtisar pelajaran }\end{array}$ & $\begin{array}{l}2 \\
3 \\
2 \\
3\end{array}$ & 2,5 & Baik \\
\hline III & $\begin{array}{l}\text { C. Penutup } \\
\text { Mennginformasikan kepada siswa untuk mempelajari materi } \\
\text { berikutnya dan mempersiapkan post test }\end{array}$ & 3 & 3 & Baik \\
\hline IV & Pengelolaan waktu & 3 & 3 & Baik \\
\hline $\mathrm{V}$ & $\begin{array}{l}\text { Pengamatan Suasana Kelas } \\
\text { Antusiasme } \\
\text { 1.Guru antusias } \\
\text { 2.Siswa antusias }\end{array}$ & $\begin{array}{l}3 \\
3\end{array}$ & 3 & Baik \\
\hline
\end{tabular}

Dari tabel 5 dapat diperoleh nilai rata-rata kemampuan guru dalam mengelola pembelajaran pada siklus II sebesar 2,93. Ini menunjukkan bahwa pembelajaran $\mathrm{f}$ yang dilaksanakan pada siklus II dengan kategori baik. Hal ini menunjukkan bahwa pengelolaan pembelajaran telah banyak meningkat. Pada siklus II ini, aspek yang telah berhasil diperbaiki adalah pengelolaan waktu. Hal ini dikarenakan guru telah terbiasa memperkirakan alokasi waktu dengan proporsi jumlah soal diperkirakan. Data hasil pengamatan aktivitas guru dalam kegiatan model pembelajaran pada siklus II disajikan pada tabel 6.

Tabel 6: Persentase Aktivitas Guru Pada Siklus II

\begin{tabular}{|l|l|r|}
\hline No & Aktivitas guru & \% Aktivitas \\
\hline 1 & Menyampaikan materi & $23,33 \%$ \\
\hline 2 & Mengamati Kegiatan Siswa & $20 \%$ \\
\hline 3 & Memberikan Latihan Terbimbing & $16,67 \%$ \\
\hline 4 & Memberikan Umpan Balik & $16,67 \%$ \\
\hline 5 & Memotivasi Siswa & $10 \%$ \\
\hline 6 & Berdiskusi/bertanya dengan siswa & $3,33 \%$ \\
\hline 7 & Perilaku Yang Tidak Relevan & $10 \%$ \\
\hline
\end{tabular}


Dari tabel 6, guru sudah tidak terlalu mendominasi dalam kegiatan pembelajaran. Hal ini dapat dilihat dari turunnya aktivitas guru dalam menyampaikan materi dari $33,33 \%$ menjadi $23,33 \%$. Guru sudah lebih baik dalam membimbing siswa menyelesaikan soal (LKS) dibandingkan dengan siklus I sebesar 13,33\% dan pada siklus II sebesar 16,67\%. Pada siklus II ini, guru sudah mengurangi perilaku yang tidak relevan dalam KBM dari 10\% menjadi 3,33 \%. Data hasil pengamatan aktivitas siswa dalam kegiatan model pembelajaran pada siklus II disajikan pada tabel 7.

Tabel 7: Persentase aktivitas siswa pada siklus II

\begin{tabular}{|l|l|r|}
\hline No & Aktivitas siswa & \% Aktivitas \\
\hline 1 & Mendengarkan penjelasan guru & $26,67 \%$ \\
\hline 2 & $\begin{array}{l}\text { Menyelesaikan tugas dari guru } \\
\text { (termasuk melihat penampilan media) }\end{array}$ & $16,67 \%$ \\
\hline 3 & Membaca buku, LKS & $13,33 \%$ \\
\hline 4 & Berdiskusi/ bertanya dengan guru & $13,33 \%$ \\
\hline 5 & Berdiskusi/ bertanya antar siswa & $6,67 \%$ \\
\hline 6 & Perilaku Yang tidak relevan & \\
\hline
\end{tabular}

Dari tabel 7 dapat dilihat bahwa aktivitas siswa dalam proses belajar mengajar pada siklus II sudah mengalami peningkatan. Hal ini dapat dilihat dari menurunya aktivitas siswa dalam mendengarkan penjelasan guru dari $36,67 \%$ pada siklus I menjadi $26,67 \%$. Siswa juga sudah terlibat aktif dalam berdiskusi/bertanya dengan guru dan dalam berdiskusi/bertanya antar siswa, pada siklus I masing-masing sebesar $10 \%$, menjadi 13,33 \% pada siklus II. aktivitas siswa dalam menyelesaikan tugas dari guru meningkat dari $13,33 \%$ pada siklus I menjadi $16,67 \%$ pada siklus II. Pada siklus II ini, aktivitas yang tidak relevan dari $10 \%$ menjadi 6,67\%. Pada akhir pembelajaran deduktifsiklus II dilakukan postest II. data ketuntasan klasikal hasil postest II siswa kelas X-5 disajikan pada tabel 8.

Tabel 8: Ringkasan Hasil Postest pada Siklus II

\begin{tabular}{|l|l|r|}
\hline No & Karakteristik & Nilai \\
\hline 1 & Jumlah Siswa & 45 \\
\hline 2 & Jumlah siswa yang tuntas $(\geq 66)$ & 40 \\
\hline 3 & Jumlah siswa yang tidak tuntas $(<66)$ & 5 \\
\hline 4 & \% ketuntasan klasikal & $88,89 \%$ \\
\hline
\end{tabular}


Berdasarkan hasil yang diperoleh dari postest II, dapat ditunjukkan bahwa pada siklus II ini diperoleh ketuntasan klasikal sebesar 88,89\%. Hal ini berarti ketuntasan klasikal sudah tercapai. (dibawah Standar Ketuntasan Belajar Minimal) sebesar 85\%. Hasil analisis secara lengkap, postest II siklus II dapat dilihat pada lampiran.

\section{c. Siklus III}

Pada siklus III pembelajaran dilakukan selama 2X40 menit, dimana 70 menit untuk kegiatan belajar mengajar dengan model pembelajaran dan 10 menit untuk melaksanakan tes akhir (postest). Adapun hasil pengamatan kegiatan pembelajaran deduktif pada siklus III disajikan pada tabel 9-12. Data hasil penilaian kemampuan guru dalam mengelola pembelajaran deduktif pada siklus III yang dinyatakan dengan rata-rata skor penilaian yang hasilnya disajikan pada tabel 9.

Tabel 9: Pengelolaan Pembelajaran

\begin{tabular}{|c|c|c|c|c|}
\hline \multirow{2}{*}{ No } & \multirow{2}{*}{ Aspek Yang Diamati } & \multicolumn{2}{|c|}{ Skor Pengamatan } & \multirow{2}{*}{ Kriteria } \\
\hline & & $X$ & Y & \\
\hline I & $\begin{array}{l}\text { A. Pendahuluan } \\
\text { 1. Mempersiapkan sarana pembelajaran } \\
\text { 2. Memotivasi siswa } \\
\text { 3. Menyampaikan indikator hasil pembelajaran } \\
\text { 4. Menghubungkan materi baru dengan pengetahuluan awal } \\
\text { siswa }\end{array}$ & $\begin{array}{l}3 \\
3 \\
3 \\
3\end{array}$ & 3 & Baik \\
\hline II & $\begin{array}{l}\text { B.Kegiatan Inti Pembelajaran berbasis konttruktivistik yang } \\
\text { kontekstul } \\
\text { 1.Abstraksi } \\
\text { a. Penguasaan kelas } \\
\text { b. Penguasaan kemampuan menjelaskan } \\
\text { c. Penguasaan teknik bertanya } \\
\text { 2. Penyajian Ilustrasi } \\
\text { a. Penguasaan materi } \\
\text { b. Kemampuan mengkomunikasikan konsep dengan cara } \\
\text { c. Kemampuan menyatakan contoh soal dengan } \\
\text { 3. Contoh yang dibuat siswa } \\
\text { a. Kemampuan mengaktifkan siswa } \\
\text { b. Kemampuan membimbing siswa } \\
\text { c. Kemampuan memantau kesulitan siswa } \\
\text { d. Kemampuan memberikan umpan balik kepada siswa } \\
\text { 4. Penutup } \\
\text { a. Kemampuan membimbing siswa untuk mengikhtisarkan } \\
\text { b. Kemampelajaran }\end{array}$ & $\begin{array}{l}3 \\
3 \\
3 \\
3 \\
3\end{array}$ & 3 & Baik \\
\hline III & $\begin{array}{l}\text { C. Penutup } \\
\text { Mennginformasikan kepada siswa untuk mempelajari materi } \\
\text { berikutnya dan mempersiapkan post test }\end{array}$ & 3 & 3 & Baik \\
\hline IV & Pengelolaan waktu & 3 & 3 & Baik \\
\hline $\mathrm{V}$ & $\begin{array}{l}\text { Pengamatan Suasana Kelas } \\
\text { A. Antusiasme } \\
\text { a. Guru antusias } \\
\text { b. Siswa antusias }\end{array}$ & $\begin{array}{l}3 \\
3 \\
\end{array}$ & 3 & Baik \\
\hline
\end{tabular}


Dari tabel 9, dapat diperoleh nilai rata-rata kemampuan guru dalam mengelola pembelajaran pada siklus III sebesar 3,00. Ini menunjukkan bahwa pembelajaran yang dilaksanakan pada siklus III dengan kategori baik.Hal ini menunjukkan bahwa pengelolaan pembelajaran telah banyak meningkat. Pada siklus III ini, aspek yang telah berhasil diperbaiki adalah pengelolaan waktu. Hal ini dikarenakan guru telah terbiasa memperkirakan alokasi waktu dengan proporsi jumlah soal diperkirakan. Data hasil pengamatan aktivitas guru dalam kegiatan model pembelajaran pada siklus III disajikan pada tabel 10 .

Tabel 10: Persentase Aktivitas Guru Pada Siklus III

\begin{tabular}{|l|l|r|}
\hline No & Aktivitas guru & \% Aktivitas \\
\hline 1 & Menyampaikan materi & $16,67 \%$ \\
\hline 2 & Mengamati Kegiatan Siswa & $16,67 \%$ \\
\hline 3 & Memberikan Latihan Terbimbing & $23,33 \%$ \\
\hline 4 & Memberikan Umpan Balik & $16,67 \%$ \\
\hline 5 & Memotivasi Siswa & $10 \%$ \\
\hline 6 & Berdiskusi/bertanya dengan siswa & $13,33 \%$ \\
\hline 7 & Perilaku Yang Tidak Relevan & $3,33 \%$ \\
\hline
\end{tabular}

Dari tabel 10, guru sudah tidak mendominasi dalam kegiatan pembelajaran. Hal ini dapat dilihat dari turunnya aktivitas guru dalam menyampaikan materi dari 23,33\% menjadi 16,67 \%. Guru sudah lebih baik dalam membimbing siswa menyelesaikan soal (LKS) dibandingkan dengan siklus II sebesar 16,67\% dan pada siklus III sebesar 23,33\%. Aktivitas guru dalam memberikan umpan balik tetap yaitu 16,67\% sedangkan aktivitas guru dalam memotivasi dan berdiskusi dengan siswa yaitu masing-masing $10 \%$ dan 13,33\%. Pada siklus III ini aktivitas yang tidak relevan sebesar 3,33\%. Data hasil pengamatan aktivitas siswa dalam kegiatan model pembelajaran pada siklus III disajikan pada tabel 11

Tabel 11 Persentase Aktivitas Siswa Pada Siklus Iii

\begin{tabular}{|l|l|r|}
\hline No & Aktivitas siswa & \multicolumn{1}{|c|}{$\%$ Aktivitas } \\
\hline 1 & Mendengarkan penjelasan guru & $23,33 \%$ \\
\hline 2 & $\begin{array}{l}\text { Menyelesaikan tugas dari guru } \\
\text { (termasuk melihat penampilan media) }\end{array}$ & $20 \%$ \\
\hline 3 & Membaca buku, LKS & $23,33 \%$ \\
\hline 4 & Berdiskusi/ bertanya dengan guru & $20 \%$ \\
\hline 5 & Berdiskusi/ bertanya antar siswa & $3,33 \%$ \\
\hline 6 & Perilaku yang tidak relevan & $10 \%$ \\
\hline
\end{tabular}


Dari tabel 11 dapat dilihat bahwa aktivitas siswa dalam proses belajar mengajar pada siklus III sudah mengalami peningkatan. Hal ini dapat dilihat dari menurunya aktivitas siswa dalam mendengarkan penjelasan guru dari $26,67 \%$ pada siklus II menjadi $23,33 \%$ pada siklus III. Siswa juga sudah terlibat aktif dalam berdiskusi/bertanya dengan guru yaitu sebesar 23,33\%. Aktivitas siswa dalam menyelesaikan tugas dari guru menurun dari $16,67 \%$ pada siklus II menjadi $10 \%$ pada siklus III. Pada siklus III ini, aktivitas yang tidak relevan menurun dari 6,67\% menjadi 3,33\%. Pada akhir pembelajaran deduktif siklus III dilakukan postest III. data ketuntasan klasikal hasil postest III siswa kelas X disajikan pada tabel 12.

Tabel 12: Ringkasan Hasil Postest pada Siklus III

\begin{tabular}{|l|l|r|}
\hline No & Karakteristik & Nilai \\
\hline 1 & Jumlah Siswa & 45 \\
\hline 2 & Jumlah siswa yang tuntas $(\geq 66)$ & 39 \\
\hline 3 & Jumlah siswa yang tidak tuntas $(<66)$ & 6 \\
\hline 4 & $\%$ ketuntasan klasikal & $86,67 \%$ \\
\hline
\end{tabular}

Berdasarkan hasil yang diperoleh dari postest III, dapat ditunjukkan bahwa pada siklus III ini diperoleh ketuntasan klasikal sebesar $86,67 \%$. Hal ini berarti ketuntasan klasikal sudah tercapai. (dibawah Standar Ketuntasan Belajar Minimal) sebesar 85\%. Hasil analisis secara lengkap, postest III siklus III dapat dilihat pada lampiran.

2. Analisis Penelitian

a. Pengelolaan Pembelajaran

Keberhasilan suatu proses belajar mengajar salah satunya ditunjang oleh kemampuan guru dalam mengelola pembelajaran. Model pembelajaran yang digunakan adalah model pembelajaran berbsis kontruktivistik yang kontektual. Selama kegiatan berlangsung, didapatkan hasil pengamatan dari aspek yang telah ditetapkan untuk diamati, maka diperoleh data penilaian kemampuan guru dalam mengelola pembelajaran sebagai berikut; 


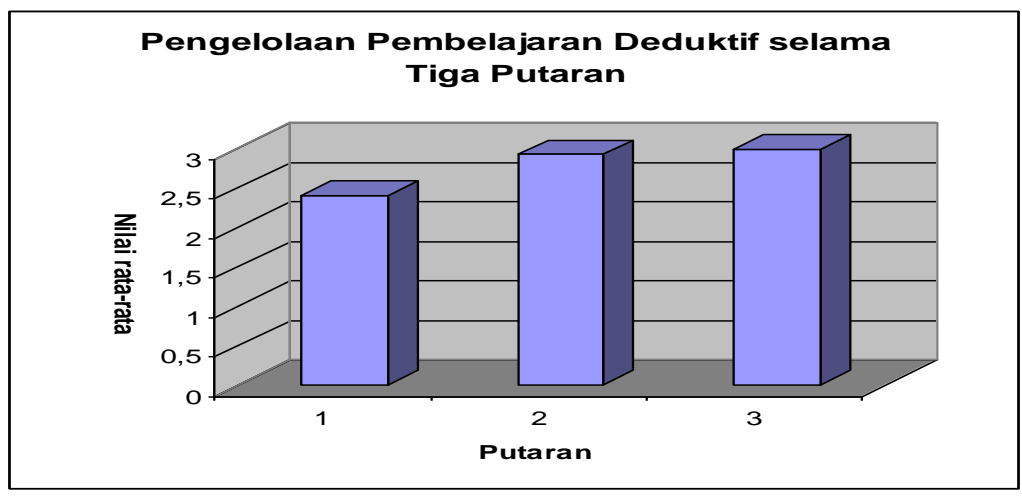

Gambar 1 Pengelolaan Pembelajaran berbasis kontruktivistik kontekstual selama tiga siklus.

Dari gambar 1, dapat dijelaskan bahwa pada siklus I nilai rata-rata kemampuan guru dalam mengelola pembelajaran adalah sebesar 2,41 dengan kategori baik. Namun ada beberapa aspek yang masih perlu diperbaiki yaitu; aspek pengelolaan waktu dan kegiatan inti pembelajaran, yaitu pada tahap abstraksi, illustrasi, contoh yang dibuat siswa dan penutup. Masing-masing dari tahap ini mendapatkan penilaian 2 (sedang) sehingga masih perlu diperbaiki. Hal ini dikarenakan guru belum terbiasa dengan model kontruktivistik yang kontekstual dan siswa sendiri masih merasa canggung sehingga pembelajaran belum berjalan maksimal.

Pada siklus III nilai rata-rata kemampuan guru dalam mengelola pembelajaran adalah sebesar 2,93 dengan kategori baik. Adapun aspek yang telah diperbaiki adalah pengelolaan waktu, namun pada aspek kemampuan mengaktifkan siswa dan kemampuan memantau kesulitan siswa masih perlu untuk diperbaiki. Hal ini dikarenakan pada siklus III, guru lebih menekankan pada kegiatan membimbing siswa agar siswa dapat menjawab dengan benar apa yang terdapat dalam LKS, dan siswa yang kurang aktif tidak mendapat perhatian dari guru.

Pada siklus III guru sudah terbiasa memperkirakan alokasi waktu, dan memperbaiki aspek-aspek yang perlu untuk diperbaiki, terbukti nilai rata-rata kemampuan guru dalam mengelola pembelajaran mengalami peningkatan menjadi 3,00 vdengan kategori baik.

b. Aktivitas Guru dan Siswa dalam Pembelajaran

1) Aktivitas Guru dalam Pembelajaran

Hasil pengamatan terhadap aktivitas guru selam tiga siklus dijelaskan pada gambar 2 . 


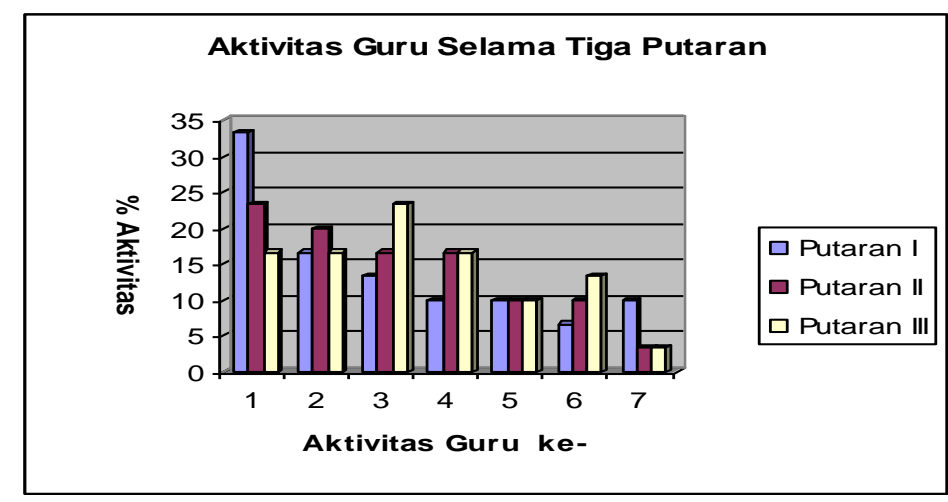

Gambar 2 Aktivitas Guru selama Tiga Siklus

Dari gambar 2 dapat dijelaskan bahwa aktivitas guru yang dominan pada siklus I adalah menyampaikan materi sebesar $33,33 \%$. Hal ini berarti pembelajaran masih berpusat pada guru dan menyebabkan siswa kurang diberi kesempatan untuk terlibat aktif dalam pembelajaran. Pada siklus II aktivitas yang dominan ini turun menjadi 23,33\%, sedangkan pada pada siklus III, aktivitas guru yang dominan yaitu memberikan latihan terbimbing sebesar $23,33 \%$ dengan demikian pembelajaran tidak lagi berpusat pada guru dan guru sudah memberi kesempatan kepada siswa untuk terlibat aktif dalam pembelajaran. Hal ini dapat dilihat dari turunya aktivitas guru dalam menyampaikan materi sebesar 6,33\%. Aktivitas guru yang lainnya pada umumnya mengalami peningkatan, spek mengamati kegiatan siswa pada siklus II $20 \%$ mengalami penurunan pada siklus III yaitu menjadi 16,67\%. Hal ini dikarenakan pada siklus III, selama pembelajaran banyak siswa yang terlambat sehingga mengakibatkan pembelajaran tidak berjalan maksimal dan guru tidak dapat mengkondisikan suasana kelas yang kondusif. Guru cenderung lebih menekankan untuk memberikan latihan terbimbing pada siswa yang belum tuntas belajarnya. Hal ini dapat dilihat pada tingginya aktivitas sguru dalam memberikan latihan terbimbing sebesar $23,33 \%$. Guru juga sudah dapat mengurangi perilaku yang tidak relevan menjadi $3,33 \%$.

2) Aktivitas Siswa dalam Pembelajaran

Hasil pengamatan terhadap aktivitas guru selaam tiga siklus didapatkan sebagai berikut: 


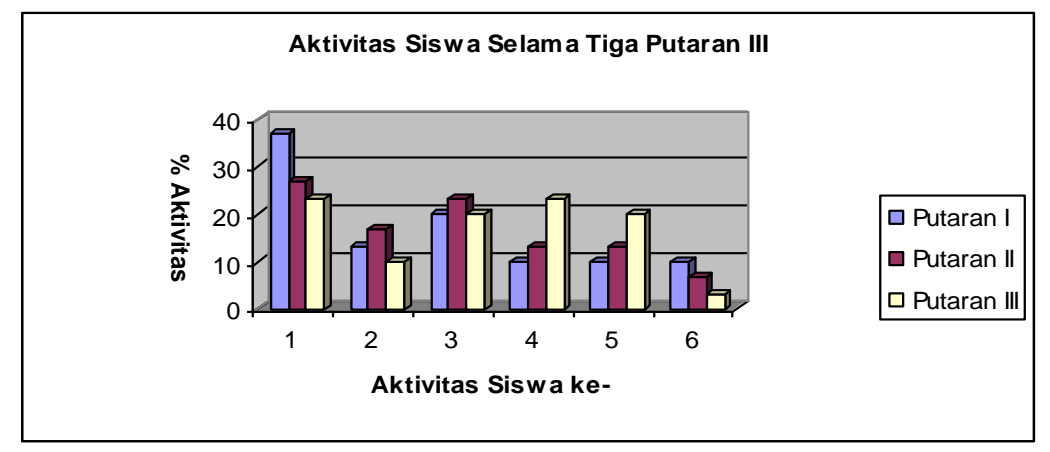

Gambar 3 Aktivitas Siswa Selama Tiga Siklus

Dari gambar 3, dapat dijelaskan bahwa pada siklus I, siswa kurang terlibat aktif dalam pembelajaran, yaitu dapat dilihat pada tingginya aktivitas siswa yang dominan yaitu mendengarkan penjelasan guru sebesar 36,67\%. Namun pada siklus II sudah mengalami penurunan, yaitu menjadi $26,67 \%$. Hal ini berarti siswa sudah mulai terlibat aktif dalam pembelajaran, sedangkan pada siklus III aktivitas siswa dalam mendengarkan turun menjadi $23,33 \%$.Siswa sudah terlibat aktif dalam pembelajaran. Aktivitas siswa yang lainnya secara umum mengalami peningkatan. Namun pada aktivitas menyelesaikan tugas dari dari guru mengalami penurunan dari siklus II sebesar $16,67 \%$ turun menjadi $10 \%$ pada siklus III. Hal ini dikarenakan siswa yang terlambat pada umumnya cenderung kesulitan dalam mengerjakan soal, karena mereka tidak mengikuti pembelajaran secara maksimal. Pada siklus III ini, siswa cenderung melakukan aktivitas dalam berdiskusi dengan guru dan antar siswa. Hal ini dapat dilihat pada tingginya aktivitas siswa ini sebesar $23,33 \%$ dan $20 \%$. Siswa juga sudah dapat mengurangi perilaku yang tidak relevan menjadi 3,33\%.

3) Ketuntasan Belajar Siswa

Penelitian Tindakan Kelas (PTK) ini diharapkan dapat meningkatkan ketuntasan belajar siswa pada materi organ tubuh manusia dan hewan. Berdasarkan kebijakan yang ditetapkan oleh SMP Muhammadiyah 10 Surabaya telah menerapkan kurikulum berbasis kompetensi, menjelaskan bahwa ketuntasan belajar al-Islam adalah jika siswa secara individu telah memperoleh nilai dengan SKBM minimal adalah nilai 66, dan ketuntasan klasikal yaitu 85\%. Data ketuntasan belajar siswa selama tiga siklus disajikan pada gambar 4.4 . 


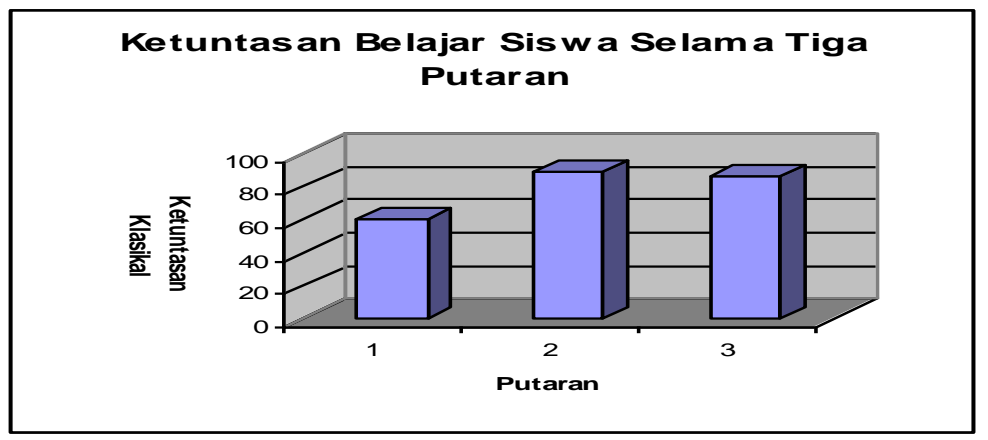

Gambar 4 Ketuntasan Belajar Siswa Selama Tiga Siklus

Berdasarkan gambar 4 diatas, dapat diketahui bahwa pada siklus I, siswa yang dinyatakan tuntas sebanyak 27 siswa dan siswa yang tidak tuntas sebanyak 18 siswa dengan ketuntasan klasikal sebesar $60 \%$. Ini berarti pembelajaran belum mencapai Standar Ketuntasan Belajar Mengajar yang telah ditetapkan sebesar 85\%. Hal ini dikarenakan siswa masih merasa canggung dan belum terbiasa dengan model pembelajaran deduktif, yang dapat berpengaruh pada ketuntasan belajar siswa. Pada siklus II, siswa yang dinyatakan dinyatakan tuntas sebanyak 40 siswa dan siswa yang tidak tuntas sebanyak 5 siswa dengan ketuntasan klasikal sebesar 88,89\%. Jika dibandingkan dengan siklus I, ketuntasan belajar siswa sudah mengalami peningkatan dan pembelajaran sudah mencapai Standar Ketuntasan Belajar Mengajar yang telah ditetapkan sebesar $85 \%$.

Pada siklus III, siswa yang dinyatakan dinyatakan tuntas sebanyak 39 siswa dan siswa yang tidak tuntas sebanyak 6 siswa dengan ketuntasan klasikal sebesar 86,67\%. Hal ini berarti pembelajaran sudah mencapai Standar Ketuntasan Belajar Mengajar yang telah ditetapkan sebesar 85\%. Namun, jika dibandingkan dengan siklus II, ketuntasan belajar siswa mengalami penurunan sebesar 2,22\%. Hal ini dikarenakan ada beberapa faktor yang berpengaruh pada ketuntasan belajar siswa, diantaranya banyaknya siswa yang terlambat secara bergiliran dalam masuk kelas, terhitung sebanyak 10 orang siswa, menyebabkan siswa yang terlambat tidak bisa mengikuti pembelajaran secara maksimal. Pada saat guru menjelaskan dan pembelajaran sedang berlangsung siswa datang secara bergiliran, secara otomatis siswa yang tidak terlambat juga merasa terganggu. Sehingga pembelajaran tidak berjalan dengan sepenuhnya dan berdampak pada ketuntasan belajar siswa. Meskipun mengalami penurunan ketuntasan klasikal, akan tetapi pada siklus III ini pembelajaran sudah mencapai Standar Ketuntasan Belajar Mengajar yang telah ditetapkan sebesar 85\%. 
Data tentang respon siswa terhadap penerapan model pembelajaran berbasis kontruktivistik yang kontaeksyual dengan media patung manusia di kelas VII SMP Muhammadiyah 10 Surabaya adalah sebagai berikut table 13:

\begin{tabular}{|l|l|c|c|}
\hline \multirow{2}{*}{ No } & \multicolumn{1}{|c|}{ Pernyataan } & Setuju & $\begin{array}{c}\text { Tidak } \\
\text { Setuju }\end{array}$ \\
\cline { 3 - 4 } 1 & $\begin{array}{l}\text { Pengajaran al-Islam dengan model pembelajaran kontekstual } \\
\text { dengan media patng manusia, air dan debu sangat menarik dan } \\
\text { tidak membosankan. }\end{array}$ & $77,78 \%$ & $22,22 \%$ \\
\hline 2 & $\begin{array}{l}\text { Dengan model pembelajaran kontruktivistik dengan media patung } \\
\text { manusia, air dan debu atau pasir berbasis kontekstul, saya lebih } \\
\text { aktif dalam proses pembelajaran. }\end{array}$ & $73,33 \%$ & $26,67 \%$ \\
\hline 3 & $\begin{array}{l}\text { Dengan model pembelajaran kontruktivstik dengan media patung } \\
\text { manusia berbasis kontekstual, saya lebih mudah memahami materi } \\
\text { organ tubuh manusia dan hewan. }\end{array}$ & $88,89 \%$ & $11,11 \%$ \\
\hline 4 & $\begin{array}{l}\text { Dengan model pembelajaran kontruktivistik dengan media patung, } \\
\text { air dan debu berbasis kontekstul, saya lebih mudah menyelesaikan } \\
\text { soal-soal dan tugas-tugas yang diberikan guru. }\end{array}$ & $86,67 \%$ & $13,33 \%$ \\
\hline 5 & $\begin{array}{l}\text { Dengan model pembelajaran kontruktvistik dengan media patung, } \\
\text { air dan debu berbasis kontekstual, saya dapat memotivasi untuk } \\
\text { belajar dan berprestasi. }\end{array}$ & $80 \%$ & $20 \%$ \\
\hline 6 & $\begin{array}{l}\text { Dengan model pembelajaran kontruktivistik dengan media patung, } \\
\text { air dan debu berbasis kontekstul, saya dapat menjelaskan yang } \\
\text { terdapat dalam definisi konsep. }\end{array}$ & $91,11 \%$ & $8,89 \%$ \\
\hline 7 & $\begin{array}{l}\text { Dengan model pembelajaran kontruktvistik dengan media patung } \\
\text { berbasis kontekstual, saya dapat memberikan contoh dari definisi } \\
\text { konsep. }\end{array}$ & $82,22 \%$ & $17,78 \%$ \\
\hline
\end{tabular}

Dari data diatas dapat diketahui bahwa respon siswa terhadap model pembelajaran dengan media patung, air dan debu berbasis kontekstual adalah positif, hal ini dapat dilihat dari nilai rata-rata dari banyaknya siswa yang menjawab setuju sebanyak $82,86 \%$. Dan siswa yang menjawab tidak setuju sebesar $17,14 \%$.

\section{Kesimpulan dan Rekomendasi}

1. Kesimpulan

Kemampuan guru dalam mengelola pembelajaran kontruktivistik yang kontekstual pada pokok bahasan wudhu, tayamum dan mandi wajib selama tiga siklus mengalami peningkatan. Pada siklus I yaitu dengan nilai rata-rata sebesar 2,41 dengan kategori baik, siklus II : 2,93 dengan kategori baik, dan siklus III sebesar 3,00 dengan kategori baik. Aktivitas guru selama pembelajaran selama tiga siklus secara umum mengalami peningkatan yaitu, pada siklus I=menyampaikan materi 33,33\%, mengamati kegiatan siswa 16,67\%, memberi latihan terbimbing 13,33\%, memberi umpan balik 10\%, memotivasi siswa 10\%, berdiskusi dengan siswa 6,67\%, dan perilaku yang tidak relevan $10 \%$. Pada siklus $\mathrm{II}=$ menyampaikan materi $23,33 \%$, 
mengamati kegiatan siswa 20\%, memberi latihan terbimbing dan memberi umpan balik $16,67 \%$, memotivasi siswa $10 \%$, berdiskusi dengan siswa $10 \%$, dan perilaku yang tidak relevan $10 \%$.Pada siklus III= menyampaikan materi $16,67 \%$, mengamati kegiatan siswa 16,67\%, memberi latihan terbimbing 23,33\%, memberi umpan balik $16,67 \%$, memotivasi siswa $10 \%$, berdiskusi dengan siswa $13,33 \%$, dan perilaku yang tidak relevan $3,33 \%$.

Aktivitas siswa selama pembelajaran selama tiga siklus secara umum mengalami peningkatan yaitu, pada siklus $\mathrm{I}=$ mendengarkan : $36,67 \%$, menyelesaikan tugas 13,33\%, membaca 20\%, berdiskusi dengan guru, berdiskusi dengan siswa, perilaku yang tidak relevan, masing-masing sebesar 10\%. Pada siklus II= mendengarkan : 26,67\%, menyelesaikan tugas $16,67 \%$, membaca $23,33 \%$, berdiskusi dengan guru 13,33\%, berdiskusi dengan siswa 13,33\% dan perilaku yang tidak relevan $6,67 \%$. Pada siklus III = mendengarkan : $23,33 \%$, menyelesaikan tugas $10 \%$, membaca $20 \%$, berdiskusi dengan guru $23,33 \%$, berdiskusi dengan siswa $20 \%$ dan perilaku yang tidak relevan $3,33 \%$.

Ketuntasan belajar siswa secara klasikal pada siklus I yaitu $60 \%$, kemudian pada siklus II meningkat menjadi $86,67 \%$ dan pada siklus III meningkat menjadi $88,89 \%$. Respon siswa pada penerapan model pembelajaran kontruktivistik yng kontekstual dengan media patung manusia, air dan debu pada materi wudhu, tayamum dan mandi wajib yaitu dengan banyaknya siswa yang menjawab setuju sebesar $82,86 \%$.

\section{Rekomendasi}

Perlu dilakukan penelitian lebih lanjut untuk penerapan model pembelajaran kontruktvistik yang kontekstual untuk materi wudhu, tayamum, dan mandi wajib berbeda dalam pembelajaran al-Islam. Guru hendaknya berusaha lebih baik dalam mempersiapkan siswa yaitu segera dapat mengkondisikan suasana kelas yang tidak kondusif dengan mengalihkan perhatian siswa dari kegiatan yang dilakukan masingmasing agar dapat terfokus untuk mengikuti pelajaran. Perlu dilakukan kegiatan dokumentasi pada saat kegiatan belajar mengajar berlangsung sebagai bukti penelitian yang telah dilakukan. 


\section{Referensi}

Asrori \& Rusman. 2020. Classroom Action Research: Pengembangan Kompetensi Guru. Purwokerto: Pena Persada

Asrori. 2019. Inovasi Belajar \& Pembelajaran PAI: Teori Aplikaif. Surabaya: UM Surabaya Press

Dave Maier. 2000. The Accelerated Learning. New York: Mc.Graw-Hill

Jamaluddin. 2001. Pembelajaran Yang Efektif. Jakarta: Bagian Proyrk EMIS Perguruan Agama Islam Tingkat Dasar

Sikidin \& dkk. 2005. Metodologi Penelitrian. Surabaya: Insan Cendikia

Sutrisno Hadi.1994. Metodologi Research II. Yogyakarta: UGM, 1994

Wina Sanjaya. 2005. Pembelajaran Dalam Implementasi Kurikulum Berbasis Kompetensi. Jakarta: Kencana

Yaumi, Muhammad. 2013. Prinsip-Prinsip Desain Pembelajaran. Jakarta: Fajar Interpratama Mandiri

Zahorik, John A. 1995. Construvtivist Teaching. Bloomington, Indiana: Phi-Delta Kappa Educational Foundation 